\title{
DIE BESTUURSVORME VAN BOTSWANA, LESOTHO
}

\section{EN SWAZILAND}

\section{A. Inleidend}

Die gebiede Botswana, Lesotho en Swaziland het tot onlangs nog amptelik bekend gestaan as Britse Hoëkommissarisgebiede. Hulle is, na verkryging van die status van Britse gebiede, bestuur en beheer deur die Britse Hoëkommissaris in Suid-Afrika, welke pos in 1909 oorgegaan het na die Goewerneur-generaal. Omdat die Goewerneur-generaal egter na 1931 aangestel sou word op advies van die Uniekabinet ,to represent the King's Grace and not the British Government" (Hailey, $1963: 1$ ), is die pos van Hoëkommissaris geskei van dié van Goewerneur-generaal. Bykomstig tot sy normale funksies as verteenwoordiger van die Britse regering in die Unie, sou die Hoëkommissaris ook belas wees met die bestuur van Swaziland, die Betsjoeanalandse Protektoraat en Basoetoland. $\mathrm{Na}$ republiekwording in 1961 het die Hoëkommissaris dan Britse Ambassadeur in Suid-Afrika geword en nog sy funksies t.o.v. die gebiede behou. $\mathrm{Na} 1962$ het daar egter 'n aksentverskuiwing in die beheerstelsel plaasgevind en is die drie Residentkommissarisse in die gebiede regstreeks verantwoordelik gemaak aan die Koloniale Sekretaris en het hulle geword "Her Majesty's Commissioners for Bechuanaland, Basutoland and Swaziland" (Hailey, 1963 : 1-3). In die daaropvolgende ontvoogdingsproses sou hulle werksaamhede beweeg na dié binne Goewerneursfeer.

Veel prominensie is in die afgelope paar jaar aan die onafhanklikwording van die gebiede gegee - dikwels met 'n blik in die rigting van die Republiek. Om die belangrikheid van die gebeure vir Suid-Afrika te onderskat, sou 'n miskenning wees van die bestaan van die kragte wat veral sedert die Tweede Wêreldoorlog in die onderontwikkelde gebiede van Asië en Afrika sterk na vore gekom het. Politieke sienings in en assosiasies van, asook orde en goeie bestuur binne die gebiede is van wesenlike belang vir Suid-Afrika se eie stabiliteit. Wat die aard van die politieke toestand in die gebiede des te belangriker maak, is die feit dat in al drie gevalle die etniese lyne nie saamval met die staatkundige grense nie. Volgens Van Warmelo $(1952: 8,17,18)$ is daar in 1946 sowat 206,000 
Swazi beskou as Unie-onderdane teenoor 204,000 Swazilandse onderdane; 748,000 Suid-Sotho as Unie-onderdane teenoor 643,000 Basoetolandse onderdane en 596,000 Tswana as Unieonderdane met 201,000 as Betsjoeanalandse onderdane. Volgens die Afrika-Instituut (Okt. 1966 : 234) was daar in 1966 sowat 30,000 Botswana-onderdane en 120,000 Lesotho-onderdane in die Republiek werksaam. Die grootste persentasie van die volke wat dus nou reeds die einde van die politieke ontvoogdingsproses beleef het, is woonagtig in die Republiek. Wat gaan die invloed van die reeds onafhanklike komponent op die nog afhanklike wees - veral as daarop gelet word dat daar nog sterk kontak tussen die volksdele oor die staatkundige grense gehandhaaf word? Nou hierby sluit ook aan die verskil in ontvoogdingspatrone tussen die R.S.A. en Brittanje. Laasgenoemde is geneig om die tradisionele te ontken ten gunste van die ,educated commoner" en aanvaar wye stemreg as grondsteen in die ontvoogdingsproses. Suid-Afrika probeer die gesag van die tradisionele owerhede bevestig en is besig om die onafhanklikheidsdeur, skarnierende op die tradisionele, oop te laat gaan. Tot welke mate kan die voormalige Hoëkommissarisgebiede die ontvoogding van die Republiekbantoe belemmer - of bevorder?

Politieke onafhanklikheid sonder ekonomiese selfstandigheid en maatskaplike weerbaarheid beteken egter geensins nasionale volwaardigheid nie. Trouens, politieke onafhanklikheid kan 'n struikelblok vir ekonomiese ontwikkeling wees omdat die buitelandse belegger ook soek na politieke stabiliteit. Soos die volkspatroon, sny ook die ekonomieë van die gebiede oor die staatkundige grense en is dit ingeskakel by die van die R.S.A. Die feit word hieronder belig. Om die bestuursvorme van die gebiede en die probleme wat daaruit voortvloei enigsins te begryp, kan die huidige nie losgesny word van tradisionele bestuursvorme nie.

\section{B. Die gebiede en hulle bevolkings}

\section{(i) Botswana}

Met 'n oppervlakte van 225,000 myl is Botswana verreweg die grootste van die drie gebiede - twaalf keer die grootte van Lesotho en Swaziland gesamentlik. Dit word, met uitsondering van Rhodesië en Zambië, begrens deur Suid-Afrikaanse of Suid-Afrikaans-beheerde gebied. Bevolkingsdigtheid is besonder 
laag -2.5 per vk. myl. Die totale bevolking het in 1964 te staan gekom op 543,105 waarvan 5,921 blank, 3,489 van gemengde herkoms, 382 Asiate en 533,275 Bantoe was. Laasgenoemde groep val uiteen in agt stamme, te wete Ngwato $(200,000)$, Kwena $(73,000)$, Ngwaketse $(71,000)$, Tswana $(42,000)$, Kgatla $(32,000)$, Malete $(14,000)$, Rolong $(11,000)$ en Tlokoa $(4,000)$.

Tot dusver kon natuurlike hulpbronne nog nie na behore ontgin word nie en geen noemenswaardige nywerheidsontwikkeling het nog in die gebied plaasgevind nie. Veeboerdery vorm die hoofbedryf en hieruit maak $89 \%$ van die bevolking, geheel of gedeeltelik, hulle bestaan. Die veebedryf het in 1965 sowat R11.3 miljoen of $85 \%$ van die totale inkomste uit uitvoere ingebring. Van alle grootvee-uitvoere was $50 \%$ na die R.S.A. Sowat $41 \%$ van alle uitvoere gaan na die R.S.A. en $70 \%$ van alle invoere kom daarvandaan. Die muntstelsel van die R.S.A. word in die gebied gebruik, en uit 'n totaal van 65,000 Batswana van Botswana wat in 1966 betaalde werk verrig het, was ongeveer 35,000 werksaam in die R.S.A. Dit het 'n bedrag van $\pm \mathrm{R} 1$ miljoen in die vorm van teruggehoue lone en remise na Botswana laat vloei (Young, $1966: 101$ ). Aansienlike bedrae is reeds belê in die ontginning van sout en soda-as (Makarikaripanne), koper (Ngwatoreserwe) en visserye (Okavangomoerasse). 'n Vyfjaar-ontwikkelingsplan (1963-68) waarin R20.5 miljoen bestee sal word, word tans uitgevoer.

Ten spyte van intensiewe pogings om die produksiesektor te verbeter en die menslike en natuurlike hulpbronne te ontwikkel, sal die gebied nog 'n onbepaalde tyd afhanklik wees van buitelandse hulpbronne. Die begroting vir 1966/67 beloop 'n geraamde uitgawe van R10 miljoen en inkomste van R5.2 miljoen. Brittanje het R5.2 miljoen beloof om tekorte te dek.

\section{(ii) Lesotho}

Alhoewel groter as Swaziland, is Lesotho die vierde kleinste onafhanklike staat in Afrika en in sy geheel omring deur grondgebied van die R.S.A. Met 'n grondoppervlakte van $11,716 \mathrm{vk}$. myl moet dit 'n de facto-bevolking van 859,000 akkommodeer; 117,000 trekarbeiders is (tydelik?) uit die gebied afwesig en hoofsaaklik in die R.S.A. werksaam. Bevolkingsdigtheid is 73 per vk. myl. Volgens die 1966-sensus tel die bevolking van Lesotho 976,000, waarvan 3,000 blankes is. Hoewel 
daar onder die Basotho verskillende volksgroepe bestaan soos Zoeloe, Temboe en Fingo (Sheddick, $1953: 74-79$ ) is dié groepe besig om te ver-Sotho en vorm ook deel van die Basothonasie. Die gesag van die tradisionele Basotho-opperhoof is deur hulle erken en hulle is geïntegreer in die tradisionele politieke struktuur van die Basotho.

Slegs $11.6 \%$ van die oppervlakte van Lesotho is geskik vir landbou. Alhoewel mielies 'n belangrike landbouproduk is, moes daar in 1965 nog 240,000 sak ingevoer word. Die uitvoerhandel bestaan uitsluitend uit landbouprodukte, waarvan $80 \%$ bestaan uit produkte verkry van lewende hawe. Wol en bokhaar maak sowat $66 \%$ van die totale uitvoerhandel uit en het in 1959 R1.9 miljoen beloop. Hoewel ons nie syfers beskikbaar het nie, was die grootste enkele bron van inkomste in 1965/66 waarskynlik die bedrag van R2.42 miljoen wat deur die R.S.A. aan Lesotho oorbetaal is ingevolge die doeane-ooreenkoms van 1910. Die 1966/67-begroting maak voorsiening vir 'n geraamde inkomste van R4.3 miljoen en uitgawe van R9.85 miljoen. Brittanje sal R5.5 miljoen skenk om tekorte te dek. Minerale neerslae is feitlik net van akademiese belang en regverdig nie grootskaalse ontginning nie. Die gebrek aan nywerheidsontwikkeling word deeglik gevoel, maar die topografie, gebrek aan verbindingsmiddele en die feit dat nyweraars nie grond in Lesotho kan koop nie - die behoort aan die Basotho en word in trust gehou deur die Koning - skrik buitelandse beleggers af. Die beoogde Oxbow-skema skep egter groot verwagtings en 'n netto wins van R1 miljoen per jaar word uiteindelik daaruit verwag.

\section{(iii) Swaziland}

Swaziland, 6,704 vk. myl groot, is afgesny van die see soos Lesotho en word, afgesien van 'n kort grenslyn met Mosambiek, omring deur Suid-Afrikaanse grondgebied. Volgens die 1966-sensus het die totale bevolking te staan gekom op 375,000 , waarvan 8,006 blank en 362,468 Swazi was. Soos die Suid-Sotho ken die Swazi ook 'n opperhoofskap en alhoewel daar in Swaziland Sotho-elemente is, is almal geïntegreer in die Swazi-nasie onder die Opperhoof.

Alhoewel die kleinste, is Swaziland die welvarendste van die drie gebiede - 'n toestand waarin die relatief groot blanke bevolking geen geringe rol gespeel het nie. Suiker 
vorm die belangrikste uitvoerartikel ( $R 9.5$ miljoen), gevolg deur die houtnywerheid ( $R 8$ miljoen in 1965). Die gebied is ook ryk aan minerale. Havelock is die vyfde grootste asbesproduseerder in die wêreld en het in 1965 asbes ter waarde van R5.7 miljoen uitgevoer. 'n Yysterertsmyn te Bomvu Ridge sal binne die volgende 10 jaar 14.5 miljoen ton ystererts aan Japan lewer vir ' $n$ inkomste van R100 miljoen. Alhoewel ryk steenkoolneerslae ook aanwesig is, het die ontginning daarvan nog nie veel aandag ontvang nie. 'n Spoorwegverbinding na Matola vanwaar oorsese markte bereik kan word ten spyt, is Swaziland se ekonomie heg ingeskakel by dié van die R.S.A. Die begroting vir 1966/67 beloop slegs R8 miljoen, maar daar is aanduidings dat Swaziland teen 1970 onafhanklik sal wees van ekonomiese bystand in die vorm van lenings of skenkings. (Afr. Inst. Bulletin, April 1967 : 80).

\section{Staatkundige ontroogding}

Die sosio-politieke doelstellings van die Britse beleid m.b.t. die gebiede onder sy beheer, hetsy kolonies, protektorate of beskermde state, is vroeg reeds aangedui as ,self-government" (Hailey, $1956:$ 146).

Die patroon van ontvoogding in die voormalige Britsafhanklike gebiede toon 'n duidelik kenbare patroon. Die tradisionele inheemse vorste word as aanvangspunt erken en aangewend as instrumente vir die handhawing van orde en behartiging van administrasie. Die "native authorities" word dan gemoderniseer, verwesters en gedemokratiseer - in Westerse sin - deur die inskakeling van die sogenaamde,educated commoners" en die inbring van verkiesings. Hand aan hand met die demokratiseringsproses gaan ' $n$ groter deelname in plaaslike bestuur wat, namate die demokratiseringsproses vorder, uitkring tot gebiedsbestuur met gereserveerde magte vir die voog. Bestuursmagte word vergroot en die bevoogde kry later 'n uitvoerende minderheid met ex officio amptenaarslede in sleutelposte. Wetgewende en uitvoerende magte gaan oor na die inheemse onder 'n Britse Goewerneur met enkele magte gereserveer vir die Britse Kroon. Laastens volg dan die toekenning van volle onafhanklikheid binne of buite die statebond (Coetzee, 1963 : 94). Die konstitusie is 'n geërfde een wat voorsiening maak vir een of twee kamers, ,skeiding van wetgewende, uitvoerende en regterlike magte, kabinet en premier, 
president of vors, kiesstelsel en party-organısasie, belydenis van vryheid en demokrasie" (Coetzee, 1963 : 95).

In twee van die drie voormalige Hoëkommissarisgebiede is hierdie proses reeds voltooi, terwyl die derde binne 'n jaar of twee ook die laaste paar grade na die volle omwenteling sal voltooi.

\section{Botswana}

Die spoor van die huidige politieke onafhanklikheid van Botswana gaan terug na 1919. In daardie jaar is 'n adviserende naturelleraad, die Native Advisory Council, ingestel bestaande uit die stamhoofde van die verskillende stamme (ampshalwe), 'n aantal verteenwoordigers uit elke stam en enkele genomineerde amptelike lede. In die daaropvolgende jaar het die blanke parallel, die European Advisory Council, bestaande uit agt verkose blanke lede en 'n paar amptelike lede, ontstaan. Uit hierdie twee rade het die Joint Advisory Council (J.A.C.) in 1950 ontstaan, bestaande uit 8 Bantoes genomineer deur die N.A.C., die 8 verkose lede van die E.A.C. en 4 lede genomineer deur die Resident-kommissaris van die Protektoraat. Na 1950 was die J.A.C. die belangrikste spreekbuis van die bevolking en het in 1958 by die Resident-kommissaris aanbeveel dat 'n Wetgewende Raad in die Protektoraat ingestel word ,to assist in the government of the Territory" (Afr. Inst.-bulletin, Febr. 1964 : 42). Spruitende uit hierdie mosie is 'n Konstitusionele Komitee aangestel ( 4 blankes, 4 Bantoes en 4 offisiële lede) om 'n konsep-konstitusie voor te berei. Die taak is in 1959 voltooi en met enkele wysigings is die grondwet in 1960 op die gebied van toepassing gemaak. Dit het voorsiening gemaak vir 'n Uitvoerende Raad van 6 amptelike en 4 nie-amptelike lede waarvan 2 blankes en 2 Bantoes moes wees. 'n Wetgewende Raad van 35 lede, waarvan 21 verkose moes wees - 10 blankes, 10 Bantoes en 1 Asiaat, word ingestel asook 'n African Council ter vervanging van die N.A.C. en bestaande uit die ResidentKommissaris en 7 amptelike lede, die stamhoofde van die 8 belangrikste stamme (ex officio) en 32 Bantoelede verkies of aangewys deur die 13 afdelings waarin die Protektoraat verdeel is. Die 10 blanke lede van die Wetgewende Raad sou verkies word deur blankes in 10 kiesafdelings terwyl die African Council sou dien as kieskollege vir die verkiesing van die 10 Bantoelede. Op 20 Junie 1961 is die Wetgewende Raad formeel 
geopen. Dit sou egter beperkte mag hê.

In 1963, dieselfde jaar waarin die pos van ResidentKommissaris omgeskep is na dié van Queen's Commissioner 'n pos met Goewerneurstatus - is samesprekings met die verskeie belangegroepe in die Protektoraat gevoer oor die verkryging van binnelandse selfbestuur. ' $n$ Ontwerpkonstitusie is met die oog hierop opgestel en op 2 Junie 1964 deur Brittanje goedgekeur. Die konstitusie waardeur selfbestuur aan die Protektoraat verleen word, het op 3 Maart 1965 in werking getree nadat ' $n$ algemene verkiesing, gebaseer op die beginsel van algemene stemreg, op 1 Maart gehou is. In die verkiesing het die Bechuanaland Democratic Party van die invloedryke Ngwatostamhoof, Seretse Khama, 28 uit 'n moontlike 31 setels in die Wetgewende Vergadering verower. Spoedig na bewindsaanvaarding het die Betsjoeanalandse regering die Britse regering versoek om 'n datum te bepaal vir onafhanklikheid. Brittanje het 30 September 1966 aangedui as datum vir die historiese gebeurtenis. 'n Onafhanklikheidsgrondwet is voorberei, deur die Betsjoeanalandse regering aanvaar en in Februarie 1966 op 'n konstitusionele konferensie bespreek, waar dit met enkele wysigings goedgekeur is. Die grondwet wat hier goedgekeur is, is met uitsondering van twee bepalings, nl. die verandering van die status van Betsjoeanaland van 'n afhanklike na ' $n$ onafhanklike gebied en die vervanging van 'n monargale deur 'n republikeinse staatsvorm, vandag van toepassing in Botswana - die nuwe naam van die voormalige Betsjoeanalandse Protektoraat.

Onder die grondwet verkry Botswana sy onafhanklikheid as die Republiek van Botswana. By die oorweging van die staatsvorm wat Botswana moes hê na onafhanklikheid, is die Wetgewende Vergadering gelei deur die feit dat die meeste voormalige Britse gebiede in Afrika vandag republieke is alhoewel hulle as monargieë onafhanklik geword het. Die vergadering was ook die mening toegedaan dat „... a monarchy would be unlikely to meet the aspirations or sentiment of the people" (Van Wyk, 1966 : 134).

Die Staatspresident is hoof van die staat en die regering, want,.. the people of Bechuanaland would expect their elected chief executive not only to exercise executive authority but also to exercise ceremonial and formal functions consistent with that authority" (ibid.). Die Staatspresident word verkies gelyktydig met die verkiesing van lede van die parlement. 'n 
Kandidaat vir die presidensiële verkiesing moet deur minstens 1000 kiesers ondersteun word en indien daar meer as een kandidaat is, word die sukses van die presidensiële kandidaat bepaal deur die sukses van die parlementêre kandidate wat op hulle nominasievorms moet aandui welke presidensiële kandidaat deur elk van hulle gesteun word. Die presidensiële kandidaat wat 'n volstrekte meerderheid kry, word dan as behoorlik verkose verklaar. Alleen in gevalle waar die President bedank of te sterwe kom, kies die Nasionale Vergadering 'n nuwe President. Die President moet ook lid van die Nasionale Vergadering wees, of binne ses maande na sy verkiesing lid daarvan word. Sodra hy ophou om lid daarvan te wees, moet hy sy amp neerlê. Indien 'n mosie van wantroue in die regering aanvaar word deur die Nasionale Vergadering, moet die President die parlement binne 3 dae ontbind en 'n algemene verkiesing uitskryf - op die vierde dag is die parlement outomaties ontbind. Die presidensiële stelsel van Botswana skyn dus 'n kompromis te wees tussen die presidensiële stelsel en kabinetsregering. Die leier van die regerende politieke party sal dus ook President wees.

Voorsiening is ook gemaak vir 'n kabinet van ses ministers plus die President wat voorsitter daarvan is. Die bevoegdheid om ministers aan te stel en af te dank, berus by die President. Die kabinet adviseer die President oor beleidsake en gesamentlik is hulle verantwoordelik vir regeringsoptrede.

Die wetgewende gesag berus by 'n parlement bestaande uit 'n Nasionale Vergadering en die President. Die Nasionale Vergadering word verkies vir 'n periode van 5 jaar volgens die beginsel van algemene stemreg en bestaan uit 31 verkose en 4 spesiaal-verkose lede, verkies deur die Nasionale Vergadering. Soos in die Transkei bestaan die parlement van Botswana uit net een huis. Die President, met die bevoegdheid om wetgewing wat deur die Nasionale Vergadering aanvaar is, daarheen terug te verwys of met ses maande te vertraag, vervul die funksie van 'n tweede kamer.

Aangesien die tradisionele stamhoofde nie as sodanig enige verteenwoordiging in die parlement het nie, is voorsiening gemaak vir 'n House of Chiefs. Die liggaam bestaan uit 15 lede: die 8 stamhoofde van die belangrikste stamme in Botswana (ex officio), vier lede verkies deur die stamhoofde van die Chobe-, Francistown-, Ghanzi- en Kgalagadi-distrikte uit hulle eie geledere, en drie spesiaal verkose lede, verkies deur 
die agt stamhoofde en vier verkose lede gesamentlik. Die House of Chiefs moet die Nasionale Vergadering adviseer en aanbevelings maak oor beoogde wetgewing wat die belange van die stamme raak en waarby sake soos stameiendom, stamorganisasie en gewoontereg betrokke is. Die liggaam het nie ' $n$ parallel in die ander Bantoestate in Suid-Afrika nie. In die Transkei ontbreek dit omdat die tradisionele element as sodanig verteenwoordig is in die wetgewende liggaam.

Die bestuursvorm van Botswana soos kortliks hierbo gestel, is vasgelê in die grondwet deur drie tipes artikels. Gewone artikels kan gewysig word deur wetgewing met die voorbehoud dat ' $\mathrm{n}$ wet tot dien effekte 30 dae voor indiening in die staatskoerant gepubliseer moet word. Die artikels handelende oor die amp van President en sy verhouding tot die Nasionale Vergadering; die samestelling en funksies van die House of Chiefs; die fundamentele regte en vryhede van die individu; staatsdiens en die pligte van die Prokureur-generaal, is egter verskans en wetgewing wat dit wil wysig moet, benewens die vereiste gestel vir gewone artikels, twee keer deur die Nasionale Vergadering met ' $n$ twee-derde meerderheid aanvaar word met 'n tydsverloop van drie maande tussen die twee goedkeurings. Die artikels wat betrekking het op die parlement - sy samestelling en bevoegdhede, afbakening van kiesafdelings en stemreg, asook die regstelsel - is spesiaal verskans en moet, behalwe die prosedure vir verskanste artikels, ook nog aan 'n referendum onderwerp word.

Vir die doeleindes van plaaslike regering word die 11 distrikte waarin die Protektoraat verdeel is onder distriksbeamptes, vervang deur nege distriksrade en drie dorpsrade (Francistown, Gaberones en Lobatsi). In vyf van die distrikte sal die stamhoof ex officio voorsitter van die distriksraad wees. Die rade word ingestel ingevolge die Local Government (District Councils) Act, 1966, waardeur vorige wetgewing in die verband herroep word. Die rade word verkies en is gemagtig om ordonnansies te maak.

Die politieke partye wat op 1 Maart 1965 meegeding het om die staatsgesag kan ideologies onderskei word as die tradisionaliste verteenwoordig deur Khama se Democratic Party, en die Pan-Afrikaniste (van verskillende grade) verteenwoordig deur die People's Party (Motsete-groep), People's Party (Mantante-groep) en die Botswana Independence Party van $M$. Mpho. In plaas van name, is kiesers voorsien van simbole: 
'n domkrag vir Khama se party; een ster vir Mantante en twee sterre vir Motsete se partye terwyl Mpho se party voorgestel is deur 'n koei. Soos reeds vermeld, het Khama se Democratic Party 28 van die 31 setels verower en $80.3 \%$ van die uitgebragte stemme op hom verenig. Die beleid van die party is gematig. Alhoewel dit nie die beleid van afsonderlike ontwikkeling onderskryf nie, sal gepoog word om vriendskaplike betrekkinge met die R.S.A. te handhaaf. Botswana is 'n lid van die V.V.O. en Organisasie vir Afrika-eenheid. Die vraag ontstaan egter hoe Khama daarin gaan slaag om sy verhouding met die R.S.A. te regverdig in die oë van Afrika - of gaan hy dalk 'n deurbraak na Afrika maak vir Suid-Afrika?

$\mathrm{Na}$ 'n tussenspel van 81 jaar het die Batswana noord van die Moloporivier weer hulle onafhanklikheid verkry. In die lewe van ' $n$ volk is dit maar 'n kort tyd. Maar in hierdie tydperk het ontwikkelings plaasgevind wat, gemeet aan die gewone gang van die Tswanageskiedenis, uiters snel was. Die nuwe staatsbestel gryp oor alle voormalige onafhanklike stamstate, en in die nuwe bestel het die gewone burger plekke geruil met die tradisionele vors. In Botswana bestaan stamgevoelens nog sterk (Hailey, $1963: 127$ ), en die vraag ontstaan hoe Khama daarin gaan slaag om die verskillende stamme te laat saamgroei tot ' $n$ nasie waarvan ook die veragte Kgalagadi en Boesman deel sal wees. Die faktore wat daartoe gelei het dat Moshoeshoe die Suid-Sothostamme en Mswati die Nguni en Sothogemeenskappe kon integreer in 'n nasie, is vandag afwesig.

\section{Lesotho}

Die instelling van die Basoetolandse Raad in 1903 kan gesien word as die beginpunt vir die huidige bestuursopset in Lesotho (Coates, 1966 : 112). Die Raad sou bloot adviserend wees en saamgestel word uit die Resident-kommissaris (voorsitter), die Opperhoof (hoofraadslid) en 99 Bantoelede waarvan 94 genomineer is deur die Opperhoof en 5 deur die Resident-kommissaris. Die funksie van die raad sou wees „.... to discuss matters affecting the domestic affairs of the nation and to express its opinion on any draft laws that might be laid before the President" (Afr. Inst.-bulletin, Maart $1964: 69$ ). In 1943 is Distriksrade ingestel. As gevolg van vertoë wat van die Distriksrade ontvang is, is die samestellingspatroon van 
die Basoetolandse Raad in 1950 verander om ruimer voorsiening te maak vir 'n verkose element. 'n Nuwe konstitusie vir die Basoetolandse Raad is in 1959 opgestel en dit het van krag geword in 1960.

Die Basoetolandse Raad word ingevolge die nuwe grondwet vervang deur die Basoetolandse Nasionale Raad, welke liggaam ook wetgewende bevoegdheid kry oor sekere sake. Dit sou bestaan uit 80 lede; 40 lede verkies deur die verkose element van die distriksrade uit hulle eie geledere, die 22 stamhoofde (ampshalwe), 4 amptelike lede en 14 lede genomineer deur die Opperhoof. Voorsiening is ook gemaak vir 'n Uitvoerende Raad, bestaande uit 4 senior amptenare en vier nie-amptelike lede van die Nasionale Raad. Die Residentkommissaris sou voorsitter wees met 'n gewone sowel as 'n beslissende stem.

Op daardie stadium het die onafhanklikheidsbal vinnig begin rol. Ingevolge 'n besluit van die Wetgewende Vergadering is 'n konstitusionele komitee in 1963 aangestel om die 1959-konstitusie te hersien en voorstelle te maak ,.... for its improvement with special reference to the introduction of responsible Government". Die komitee het nog in 1963 verslag uitgebring. Vervolgens is 'n konstitusionele konferensie in Londen gehou waarby alle politieke partye sowel as die Opperhoof teenwoordig was. Met enkele wysigings is die konsepgrondwet goedgekeur waardeur Basoetoland selfregering sou kry. Die grondwet sou in werking tree nadat ' $n$ algemene verkiesing plaasgevind het. 'n Jaar na die inwerkingtreding van die grondwet sou Brittanje, indien die Basoetolandse parlement ' $n$ mosie tot dien effekte aanvaar of ' $n$ referendum so aantoon, bereid wees om onafhanklikheid aan die gebied toe te staan.

In April 1965 is die algemene verkiesing gehou. Tot verrassing van die Basutoland Congress Party het Leabua Jonathan se Basutoland National Party, wat in die 1960-verkiesing net een setel kon verower, nou 29 setels ingepalm teenoor die Congress Party se 25 en Marematlou Freedom Party se 4. Die konstitusie wat nou in werking getree het sou ook, met enkele wysigings, die grondwet van die onafhanklike Lesotho wees 'n status wat op 4 Oktober 1966 verkry is na moleste deur die Opperhoof en opposisiepartye.

Volgens die grondwet staan Basoetoland bekend as Lesotho met die Opperhoof, Moshoeshoe II, as die Koning. (Die 
Opperhoof het in die periode onmiddellik voor onafhanklikheid sy konstitusionele funksies uitgeoefen in naam van die Koningin van Engeland). Hy moet ooreenkomstig die raad van sy ministers optree, behalwe in sake wat betrekking het op die aanstelling van sekere lede van die Senaat, die toekenning van grond en tugmaatreëls teen stamhoofde. Die prerogatief van begenadiging berus ook by die Koning. Lesotho is dus ' $n$ konstitusionele monargie - die eerste staat in Afrika om as 'n monargie onafhanklik te word sonder dat die Britse Koningin die monarg of staatshoof is. Indien die Koning nie meer in staat is om sy funksies uit te voer nie, sal dit die taak van die College of Chiefs wees om 'n opvolger vir hom aan te wys.

Die parlement bestaan uit twee huise, 'n Nasionale Vergadering en 'n Senaat. Die Nasionale Vergadering bestaan uit 60 lede verkies in 60 kiesafdelings op die basis van algemene stemreg vir volwassenes. Die Senaat bestaan uit die 22 stamhoofde (ex officio) of hulle verteenwoordigers en 11 persone volgens eie diskresie deur die Koning benoem. As hy die 11 Senatore benoem, moet hy egter sy Geheime Raad raadpleeg, alhoewel hy nie aan hulle advies gebonde is nie. In teenstelling met Botswana waar die tradisionele stamhoofde as sodanig geen plek in die parlement toegesê is nie - hulle is saamgetrek in 'n adviserende House of Chiefs - domineer hulle die Senaat in Lesotho.

Die uitvoerende gesag berus by die Koning, handelende op advies van die kabinet bestaande uit 'n Eerste Minister aangestel deur die Koning, Adjunk-Eerste Minister en 'n aantal ander ministers. Die kabinet moet die Koning inlig oor regeringsake en hulle is kollektief verantwoordelik aan die parlement.

Artikel 80 van die grondwet maak voorsiening vir 'n King's Privy Council. Die Raad bestaan uit die Eerste Minister, 'n genomineerde deur die Koning en 'n genomineerde deur die Eerste Minister, aangestel deur die Koning. Die raad moet die Koning van advies dien in sake waaroor hy „volgens eie diskresie" kan besluit.

Die grond is die besitting van die Basotho en alhoewel die parlement reëls oor die toekenning van grond kan opstel, sal dit beheer word deur die Koning op advies van die College of Chiefs. In die toekenning van grond sal die stamhoofde 'n sleutelrol speel en word hulle bygestaan deur 'n adviesraad 
van 7 lede verkies op 'n pitso (stamvergadering), 2 benoemdes van die stamhoof en 2 lede genomineer deur die Minister.

Voorsiening is ook gemaak vir die instelling van 'n College of Chiefs. Die liggaam bestaan uit die 22 stamhoofde en kan lede koöpteer met dien verstande dat nie meer as drie gekoöpteerde lede gelyktydig sitting kan hề nie. Die gekoöpteerde lede het ook nie stemreg nie. Die liggaam is verantwoordelik vir die aanwysing van 'n opvolger by die dood of abdikasie van die Koning. 'n Aanspraakmaker op die troon wie se aanspraak deur die kollege verwerp is, kan teen die beslissing appèl aanteken by die Hoë Hof van Basoetoland. Uit die kollege word ook 'n Vaste Komitee saamgestel wat aandag moet gee aan die take van die liggaam volgens prosedures wat self gereël kan word. Die handelinge van die liggaam moet volgens tradisionele Basoetoreg en -gebruik wees. Sowel in samestelling as funksies verskil die College of Chiefs dus van die House of Chiefs van Botswana.

Die stelsel wat in die lewe geroep is vir regspleging, kom in breë trekke grootliks ooreen in Botswana en Lesotho. Appèl kan aangeteken word van die laer howe na die Hoë Hof en daarvandaan na die Appèlhof. Waar daar voorheen net een Appèlhof vir al drie die Hoëkommissarisgebiede bestaan het, het Botswana en Lesotho nou elk 'n eie Appèlhof onder 'n Hoofregter aangestel deur die President en Koning op advies van die Eerste Minister, onderskeidelik. Voorsiening is ook gemaak dat appèlle in sekere sake verwys kan word na die Regskomitee van die Geheime Raad in Brittanje (Botsw. Ind. Act., 1966, art. 5 (1)).

Lesotho is vir die doeleindes van plaaslike administrasie verdeel in 9 distrikte, elk onder 'n distriksbeampte (Stateman's Yearbook 1966-67:145). Elke distrik is weer onderverdeel in wyke waaroor lede van die heersersfamilie aangestel is volgens die tradisionele bestuursmetode. In alle sake rakende Basoetoreg en -gebruik is hulle verantwoording verskuldig aan die Koning.

Van die politieke partye in Lesotho, is die konserwatiefste tans aan bewind. Die leier van die opposisieparty, die Basutoland Congres Party, is 'n apostel van Nkrumahisme, gereëlde besoeker aan Peking, anti-blank (,hulle is bloedsuiers") en sou by geleentheid gesê het: „There is no God. It is not God who gives you bread, it is the Basutoland Congress Party". (Afr. Inst.-bulletin, Maart 1964 : 79). Die Marematlou Freedom 
Party is minder ekstremisties, dog,$\ldots$ we recognise our own national struggle as having a direct bearing on the struggle of our neighbouring brothers and sisters in... South Africa, South West Africa and elsewhere..." (Afr. Inst.-bulletin, Mrt. 1964 : 76). Politieke bande met die R.S.A. word verwerp en eer word betoon aan die „vryheidsvegters" in Afrika. As vooruitsig word gestel 'n verenigde Afrika op 'n federale basis. Dr. Seth Makotoko staan aan die hoof van hierdie party, wat ook sterk Kommunistiese affiliasies het en sy middele, soos die Congress Party, uit Kommunistiese bronne kry. In teenstelling met die vorige twee, kry die regerende Basutoland National Party weinig finansiële steun van buite Basoetoland. Die leiding van die party is in die hande van stamhoofde en is in 1959 gestig ,.... to safeguard the traditional way of life of the Basuto". Jonathan het reeds bewys gelewer dat hy 'n realistiese staatsman is en nouer voeling met die R.S.A. soek. Dit is nie onmoontlik nie dat die opposisiepartye weer 'n onkonstitusionele poging sal aanwend om die bestuur van Lesotho oor te neem. Indien hulle sou slaag, sal Lesotho omgeskep word in 'n vyandige Kommunistiese broeines en springplank vir gesagsondermynende aktiwiteite in die R.S.A.

\section{Swaziland}

In 1921 is die European Advisory Council ingestel. Die raad sou bestaan uit verkose blankes, is hersaamgestel in 1949 en het as hooffunksie gehad die advisering van die Resident-kommissaris ,... on matters directly affecting the European residents of the Territory and on any matters specifically referred to the Council by the Resident Commissioner". Die raad het in 1949 bestaan uit 16 lede; 10 verkies en 6 amptelike lede benoem deur die Kommissaris. Vir die verteenwoordiging van Swazibelange het die Opperhoof-in-rade nog steeds gedien as kontakpunt tussen die administrasie en die Swazivolk. Vir belangrike sake is die Libandhla byeengeroep, maar deurgaans sou die Liqoqo optree in sake rakende die Swazi. Uit die Liqoqo is dan ook 'n komitee benoem om deur weeklikse vergaderings met 'n amptenaar, kontak met die regering van Swaziland te hou. As belangrike nuwigheid is die Swazi Progressive Association in 1929 o.l.v. die destydse Kommissaris gestig. Die beweging moes 'n „party for Africans” wees, want die Kommissaris „desired to hear the opinion of 
the enlightened Africans of the country on any subject concerning the administration and development of the Country". Die "party" het 'n oënskynlik nuttelose bestaan gevoer tot en met 1960, toe dit omgeskep is in die Swaziland Progressive Party ,ten einde die heersende politieke situasie die hoof te bied".

In teenstelling met die res van die jonger Afrika het die inisiatief vir onafhanklikheid in die geval van Swaziland uitgegaan van die Blanke Adviesraad. Die raad het in 'n memorandum in 1960 gerig aan die Britse regering, die wenslikheid van ' $n$ veelrassige wetgewende liggaam bepleit. Die Opperhoof het die voorstel gesteun en 'n konstitusionele komitee is aangestel om 'n konsep-grondwet op te stel. Daarna volg 'n konstitusionele konferensie in Londen. Omdat die verteenwoordigers van die Libandhla en Adviesraad aan die een kant en politieke partye aan die ander kant nie mekaar kon vind oor die bepalings van die grondwet nie, het die Britse Secretary of State op eie verantwoordelikheid besluit wat die bepalings van die grondwet moes wees. Eienaardig dat die wense van die politieke partye groter beslag gekry het in die konstitusie as die van die Libandhla en Adviesraad. Teen die einde van Mei 1963 is die finale grondwet afgekondig.

Die konstitusie het voorsiening gemaak vir die vervanging van die Resident-kommissaris deur 'n Queen's Commissioner met Goewerneurstatus, 'n Wetgewende Vergadering en 'n Uitvoerende Raad. Die Wetgewende Vergadering sou bestaan uit 'n Speaker en 32 lede; 4 amptenare, 4 lede genomineer deur die Kommissaris, 8 Swazi's op tradisionele wyse verkies, 8 blankes ( 4 verkies deur blanke kiesers en 4 deur kiesers van alle rasse) en 8 lede van enige ras verkies deur kiesers van alle rasse. Die uitvoerende gesag sou berus by die Kommissaris bygestaan deur die Uitvoerende Raad bestaande uit 4 amptenare en 4 nie-amptelike lede -2 blankes en 2 Swazi's. 'n Aantal gespesifiseerde sake sou gereël word deur Swazireg en -gebruik en daaroor sou die Wetgewende Vergadering geen maatreëls kon maak nie.

Feitlik alle groepe in Swaziland was teen die konstitusie gekant. Die Opperhoof-in-libandhla het geredeneer dat Swaziland ' $n$ beskermde staat is en geregtig is om onafhanklikheid te kry sodra die gebied tot so 'n mate ontwikkel het dat dit die verantwoordelikheid verbonde aan onafhanklikheid kan dra. Gevolglik het Brittanje geen reg om oor die bestuursvorm 
van 'n onafhanklike Swaziland te beslis nie: die Swazi het dit volgens eie resep bestuur vóór 1903 en die vorm moet ook geld na onafhanklikheid - slegs vir die blankes moet 'n vorm van verteenwoordiging gevind word. Een-man-een-stem lei tot misverstand en misbruik. Die Swazi in die parlement moet dus verteenwoordig word deur die Libandhla. Die Swazi-politieke partye was ook ontevrede - omdat die parlement nie saamgestel word suiwer uit verkose lede verkies volgens algemene stemreg nie. Die reservering van setels is uit die bose en kan daartoe lei dat die blankes hulle posisie in Swaziland konsolideer ,(it) aims at retaining permanently imperialism, neocolonialism and exploitation" (Afr. Inst.-bulletin, Apr. 1964 : 123). Die blankes in Swaziland het hulle geskaar aan die kant van die Opperhoof, terwyl die simpatie van die Britse amptenare gelê het by die „ontluikende” politieke partye. Die bepalings van die omstrede grondwet sou in werking tree nadat die eerste algemene verkiesing in die geskiedenis van die Swazivolk plaasgevind het. In Junie 1964 het die verkiesing plaasgevind.

Op die vooraand van die verkiesing is die Imbokodvo National Movement onder leiding van die Opperhoof georganiseer omdat die tradisionaliste op daardie stadium nog geen mondstuk in die vorm van 'n politieke party gehad het nie. Kandidate is genomineer en die verkiesingsuitslag het getoon dat die Swazi nog tradisievas is. Imbokodvo het 16 uit die 24 setels ingepalm en die bondgenoot van Imbokodvo, die blanke United Swaziland Association, het die orige 8 setels verower. Die uitslag het as ' $n$ teleurstelling vir die Britse amptenare gekom en daarin is waarskynlik geleë die rede waarom Swaziland nog nie onafhanklik is nie. Brittanje weerhou onafhanklikheid met die hoop dat die nie-tradisionaliste in krag sal toeneem en die tradisionaliste van die politieke troon sal stoot. Ten spyte van hardnekkige teenstand deur die „opposisie", wat beweer het dat Sobhuza se oogmerk 'n „tirannieke en meedoënlose stamdiktatuur" is, het die Wetgewende Vergadering in 1966 konstitusionele voorstelle vir die toestaan van selfregering aan Swaziland aanvaar. Dit is deur Brittanje goedgekeur en sou op 1 Maart 1967 in werking tree nadat die tweede verkiesing in Swaziland plaasgevind het. Die verkiesing het in April 1967 plaasgevind. In die verkiesing het Imbodkodvo al 24 setels in die Wetgewende Vergadering verower. Op 25 April 1967 is selfbestuur aan Swaziland toegestaan. Die huidige 
grondwet sal waarskynlik met enkele wysigings die grondwet van die onafhanklike Swaziland wees - 'n status wat volgens 'n Britse witskrif in 1969 aan Swaziland toegesê sal word.

Onder die huidige grondwet word groter bestuursmagte oorgedra aan Swaziland, maar die Queen's Commissioner sal nog verantwoordelik wees vir buitelandse sake, binnelandse veiligheid, diensvoorwaardes van staatsamptenare en kontrole oor finansiële besteding.

Die Ngwenyama (Opperhoof) is die Koning van Swaziland en hoof van die staat. Hy word aangestel ooreenkomstig Swazireg en -gebruik. Ook die posisie van die Ndlovukazi (Koninginmoeder) word erken en haar opvolger sal ook ooreenkomstig Swazireg en -gebruik aangestel word. Verder sal die Ndlovukazi as regent optree as die koning te sterwe kom of as die troon op enige ander wyse vakant raak tydens die minderjarigheid van die manlike opvolger uit die jonger generasie. Die Koning en Koningin-moeder is ook regsimmuun. Verdere sake wat uitsluitlik deur Swazireg en -gebruik gereël sal word, is die aanstelling en skorsing van stamhoofde, die samestelling van die Libandhla, die regimentestelsel en die ncwala-seremonie. In plaas van 'n „Privy Council” soos in Lesotho, sal die Ngwenyama ook geadviseer word deur die Libandhla (Swaziland Constitutional Order, 1967, H. XII).

Die Parlement bestaan uit die Koning, 'n Senaat en 'n Algemene Vergadering. Die Senaat bestaan uit 12 lede -6 verkies deur die Algemene Vergadering en 6 lede benoem deur die Koning volgens eie diskresie. Hierdie benoemde lede moet egter benoem word op grond van hulle kennis van landsake, sodat die benoemings bevorderlik sal wees vir die regering van sosioekonomiese ontwikkeling van Swaziland en moet nie daarop bereken wees om 'n meerderheidsparty te kortwiek nie. Die Algemene Vergadering bestaan uit 24 verkose lede verkies in agt kiesafdelings ( 3 per kiesafdeling), 6 lede genomineer deur die Koning, plus die Prokureur-generaal - ook aangestel deur die Koning. As vereiste vir stemreg word gestel burgerskap van Swaziland en 'n ouderdom van 21 jaar.

Die uitvoerende gesag berus by die Koning op advies van die Kabinet. Die Eerste Minister word aangestel deur die Koning. Die Kabinet moet die Koning adviseer in die uitoefening van sy funksies en hy het die mag om die Kabinet binne 14 dae te vra om gegewe advies te hersien. Indien die Kabinet egter sou volhard in sy advies, moet die Koning dit aanvaar. 
Dit is egter slegs Kabinetsadvies wat deur die Koning aanvaar moet word en nie advies gegee deur ander adviesbronne nie. Die Kabinet moet die Koning en Kommissaris ook ingelig hou oor alle belangrike regeringsake. Die prerogatief van begenadiging berus by die Koning op advies van 'n Begenadigingskomitee bestaande uit die Prokureur-generaal en drie ministers vir die doel aangestel deur die Koning. Die finale besluit lê egter by die Koning.

As 'n skynbaar tussentydse stap totdat onafhanklikheid toegestaan word, word voorsiening gemaak vir 'n Konsultatiewe Raad bestaande uit die Kommissaris (voorsitter), Eerste Minister, Adjunk-kommissaris en Adjunk-Eerste Minister. Die raad moet beleid neerlê oor die wyse waarop die Kommissaris uitvoering moet gee aan die nog vir die Britse Kroon gereserveerde magte sodat dit in die beste belang van Swaziland sal wees.

Swazigrond word deur die Koning in trust gehou vir die Swazi. Hoewel die regering die bevoegdheid het om wette te maak oor grond, mag dit nie oorgedra word aan 'n ander gesag nie. So ook mineraleregte.

Verder is voorsiening gemaak vir 'n Appèlhof vir Swaziland, 'n Staatsdienskommissie, beheer oor finansies en burgerskap. Tot tyd en wyl Swaziland onafhanklik is, stel die Kommissaris regters aan.

Soos in Lesotho en Botswana, bestaan die grondwet in gewone artikels, verskanste en spesiaal verskanste artikels. 'n Gewone artikel kan gewysig word deur 'n wysigingswet met dien verstande dat sodanige wysigingswet drie maande na indiening bespreek moet word by 'n gesamentlike sitting van albei huise en dit ' $n$ maand na die debat deur albei huise met 'n gewone meerderheid goedgekeur moet word. Daarna kan dit na die verteenwoordiger van die Britse Koningin verwys word vir goedkeuring. Vir ' $n$ verskanste artikel moet dieselfde prosedure gevolg word, maar in plaas van 'n gewone meerderheid, moet die wysigingswet met ' $n$ driekwart-meerderheid goedgekeur word. 'n Spesiaal verskanste artikel kan gewysig word na 'n debat, goedkeuring met 'n driekwart-meerderheid en 'n referendum waarin twee derdes van die stemgeregtigdes hulle ten gunste van die wysiging uitspreek.

Die regerende party in Swaziland, Imbokodvo, geniet die ondersteuning van die blanke United Swaziland Association ingevolge 'n ooreenkoms tussen die twee partye bekend as 
Imbokodvo Mbalala - "die maalklip met baie kleure" (Afr. Inst.-bulletin, Apr. 1967 : 82). Die U.S.A. het ook nie kandidate vir die April-verkiesings gestel nie, maar Imbokodvo gesteun. Die party (Imbokodvo) word, hoewel nie uitdruklik nie, deur die Koning beheer terwyl Prins Makhosini Dlhamini leier van die party en gevolglik Eerste Minister van Swaziland is. In 1966 het Makhosini anngekondig dat die beleid van Imbokodvo die patroon sal volg wat deur Jonathan vir Lesotho en Khama vir Botswana neergelê is. Die beleid sou neerkom op 'n "gesonde verstandhouding" met sy buurstate en geen inmenging in die binnelandse sake van ander lande nie. Ekonomiese bande met die R.S.A. sal gehandhaaf word en Swaziland sal in 'n toenemende mate staatmaak op tegniese hulp uit die R.S.A. Hierteenoor staan die Ngwane Liberatory Congress wat min of meer as verteenwoordigend van die "opposisiepartye" aanvaar kan word (met uitsondering van die meer gematigde Swaziland Democratic Party), Pan-Afrikanisties, gevoed (met gedagtes sowel as fondse) deur Kommunistiese en na-kommunisties-oorhellende bronne. Die tipiese Afrika-onafhanklikheidscliché's word ook deur die party gebruik: „weg met imperialisme, kolonialisme...", „one man, one vote...", „ons broers in Afrika...", „blankes moet op hulle plek gesit word..." Afrika-sosialisme. Die partye hoop om aanhangers te trek uit die geledere van die meer "ontwikkelde" Swazi uit die dorpsgebiede - 'n klas wat blaarblyklik maar skaars is.

Swaziland het dus ' $n$ de facto-eenparty-regering en dit is te betwyfel of daar in die nabye toekoms enige verandering in die opset sal kom. Die Eerste Minister het reeds aangedui dat Imbokodvo gaan probeer om Swaziland voor 1969 onafhanklik te hê. Met Brittanje buite die prent, het die verskansing van artikels feitlik geen betekenis nie. Die wil van die regerende party is die wil van die volk en die party hou nie van die Westminster-demokrasie nie.

\section{Slotopmerkings}

Tussen die bestuursvorme van die drie voormalige Hoëkommissarisgebiede bestaan daar dus aanmerklike verskille. Botswana is ' $n$ republiek met die leier van die regerende party as president. Daar bestaan ook nie 'n tweede kamer nie die president sal die funksies van die tweede kamer vervul. Hierteenoor is Lesotho en Swaziland konstitusionele monargië 
waarin die tradisionele vors as konstitusionele monarg die staatshoof is. In stryd met die tradisionele bestuursopset, sal die staatshoofde van Lesotho en Swaziland nie regeringshoofde wees nie, en hierdie vreemdheid het in Lesotho reeds aanleiding gegee tot ' $n$ magstryd tussen die Koning en die Eerste Minister waarin etlike Basoetos gedood en die Koning uiteindelik onder huisarres geplaas is. Die staatshoof het geredeneer: ,it was never the intention of the Basuto people... to see its hereditary leader drop to the level of a deaf and dumb person" (Afr. Inst.bulletin, Apr. $1967: 10$ ). Ten einde sy sin te probeer kry, was die staatshoof ook bereid om in samewerking met die opposisiepartye 'n staatsgreep teen die regering te beplan. Hierdie insident toon aan dat ' $n$ nuwe bestuursvorm nie maar soos 'n kledingstuk aangetrek kan word nie.

In die samestelling van die parlement bestaan daar ook duidelike verskille, veral met betrekking tot die plek wat aan die stamhoofde toegesê is. Botswana het geen plek vir hulle gemaak in die parlement nie, maar hulle saamgetrek in 'n adviserende liggaam en hulle advies word slegs oor sekere sake verlang. Lesotho het hulle geplaas in die tweede kamer waar hulle voortdurend ' $n$ tweederde-meerderheid uitmaak en gevolglik die regerende party kan kortwiek omdat hulle nie verbonde is aan 'n politieke party nie. Swaziland het ook geen amptelike plek aan hulle toegesê nie, maar die regerende party kan feitlik beskou word as die beliggaming van die waardes waarvolgens hulle leef en optree. Presies waar om die tradisionele stamhoofde in die nuwe bedeling te plaas vorm ' $n$ probleem. Indien geplaas as ex officio-lede in die laerhuis soos in die Transkei, kan hulle 'n drukgroep vorm en die uitvoering van beleid in die wiele ry - veral as die regerende party nie ' $n$ oorgrote meerderheid in die parlement het nie. Maar ook is dit seker die effektiefste manier om die stamhoofskap nek om te draai. Hier bevind die ongeleerde kandidaat van die bloedlyn hom teenoor die geskoolde politikus wat nie sal huiwer om die bedreigende tradisionele bloedhoof te onderploeg en belaglik te maak nie. En die stamhoof is deeglik bewus van hierdie onbenydenswaardige posisie waarin hy verkeer (Hammond - Tooke 1964: 527). Indien geplaas in die hoërhuis, tree die probleem van Lesotho op die voorgrond. Indien nie as sodanig verteenwoordig in die parlement nie, kan dit 'n permanente belemmering vir die vorming van nasieskap beteken, werk politieke partye stamsgewys en ly 
die belange van die kleinere stamme daaronder. Daarbenewens is die miskenning van die gesag van die tradisionele stamhoofde in die regeringsproses ' $n$ goeie resep vir onluste en rebellies. Selfs dr. Nkrumah het 'n konfrontasie met die stamhooforde in die "verligte" Ghana vermy (Williams, 1966 : 216-217).

Dit is ook opmerklik dat in al drie gebiede die konserwatiefste party aan bewind is en dit is nie sonder betekenis nie dat sir Seretse Khama, hoewel afgesit deur die Britse administrasie, "die hoogste bloed" in die groot Ngwatostam het en die stam besluit het dat Khama se kinders eerste aanspraak op die Ngwatotroon het. Jonathan is 'n kleinseun van Moshoeshoe I, behoort dus tot die aristokratiese Koena-stam en is self 'n stamhoof. So ook is Makhosini Dlhamini ' $n$ prins van die aristokratiese Dlhamini-clan waaronder die Swazi ontstaan het. Die opposisieleiers in die gebiede het met een uitsondering nie tradisionele status nie en hulle invloedsfeer is beperk tot enkele dorpsgebiede. Aanhang word hoofsaaklik gekry uit die geledere van die Bantoe wat reeds die stamverband ontgroei het. In Lesotho is lojaliteite egter vertroebel deurdat die Koning hom geskaar het aan die kant van die opposisie. Met uitsondering van Lesotho het die regerende partye feitlik 'n vry hand in staatsake omdat opposisie feitlik ontbreek. Steek daar enige sin in die verskansing van sekere artikels van die grondwet onder sulke omstandighede?

Die houding wat deur die opposisie ingeneem is in die gebiede, toon ook 'n duidelike ooreenkoms. Afrika het reeds bewys dat die party wat met onafhanklikwording aan bewind is, aan bewind bly totdat dit op onkonstitusionele wyse uit die saal gelig word. Die opposisie in die gebiede was dan ook teen die toestaan van onafhanklikheid gekant voordat 'n (onnodige) verdere verkiesing gehou is en het die hoop gekoester dat hulle deur so 'n verkiesing aan bewind sou kom. In Lesotho is verwys na die "minderheidsbewind van Jonathan". In Botswana het Mantante verklaar dat die regering nie 'n mandaat van die kiesers het om die gebied na onafhanklikheid te lei nie. Die Swazilandse opposisie het eweneens selfbestuur onder 'n "meedoënlose stamdiktatuur" teengestaan. En ironies, was „onafhanklikheid so spoedig moontlik" een van die lokmiddels wat deur hulle aan die kiesers voorgehou is.

Om op hierdie stadium ' $n$ finale mening uit te spreek oor die werking van die bestuurstelsels in die drie gebiede, 
is onmoontlik. Dit kan egter gestel word dat die bestuurstelsels wat aan die gebiede gegee is nie ' $n$ produk van die Bantoegemeenskappe van die gebiede is nie. Die werking daarvan is vir die groot gros 'n onverstaanbare geheim. Gevolglik kan dit nie beskou word as 'n kultuurneerslag op die politieke terrein nie. Die noodsaaklike korrespondensie tussen die maatskappy en bestuursvorm is afwesig. Bestuurstegnieke wat in Westerse gemeenskappe ontstaan en gegroei het, is oorgeplant met die hoop dat dit lewensvatbaarheid sal toon. Dit moet egter aanvaar word dat die stelsels sal verander. Indien die grondliggende filosofie daarvan nie begryp word nie, en indien dit nie aansluiting kan vind by die waardes van die Bantoesamelewings nie, kan kwalik verwag word dat dit ongewysigd moet voortbestaan en nog demokraties genoem word.

Afrika is besig om 'n kompromis te bewerkstellig tussen die Westerse geërfde bestuursvorm en die tradisionele bestuursmetode. Dit hang saam met die versugting na 'n eie identiteit - negritude, African personality, Afrika-sosialisme. Tanzanië het reeds bevind: „The distinction between government and party has never been understood by the people" (Afr. Inst.-bulletin, Julie $1965: 157$ ) en Afrika beroem hom daarop dat sy bydrae tot die teorie en praktyk van die demokrasie die wyse is waarop hy die Westerse bestuursvorme met slegs een party laat funksioneer (Cloete $1967: 12$ ).

Wat die finale bestuursvorm in die gebiede sal wees, is moeilik om te voorspel. Een feit kan egter aanvaar word: soos wat Brittanje die "native authorities" as aanvangspunt erken het, het die gebiede die Westminister-demokrasie ook as aanvangspunt erken.

C. J. Maritz.

14 Junie 1967.

\section{LITERATUURLYS}

Afrika-Instituut, Pretoria. Verskeie Bulletins van die...

Cloete, J. J. N.: Swart Afrika - Politiek en administratiewe tendense. Afrika-Instituut, Pretoria, 1966.

Coates, A.: Basutoland, H.M.S.O., Londen, 1966.

Coetzee, J. H.:

(a) Inboorlingowerhede en die politieke ontwikkeling van Afrika. Koers, Nov.-Des. 1962.

(b) Politieke ontwikkeling, probleme en vooruitsigte in die jongere onafhanklike Afrikastate. Bulletin Afr. Instituut, Pta., Mei 1963. 
(c) Swaziland: Staatkundige, administratiewe en politieke aspekte, 1964.

Hailey, Lord:

(a) Native Administration in the British African Territories, Part V., H.M.S.O., 1953.

(b) An African Survey (Revised 1956). O.U.P., 1957.

(c) South Africa and the High Commission Territories. O.U.P., 1963.

Hammond-Tooke, W. D.: Chieftainship in Transkeian Political Development. Journal of Modern African Studies, 2 (4): 1964.

Henning, J. J.: Konstitusionele ontwikkeling in Basoetoland. Blik op Afrika. Pro-Rege, 1962.

Lestrade, G. P.: Some notes on the political organisation of the Bechwana. S.A.J.S., Dec. 1928

Schapera, I.: The Tswana. London, 1963 (1962).

Sheddick, V. G. J.: The Southern Sotho. Londen, 1953

Stateman's Yearbook, 1966-67.

Stow, G.: The Native Races of South Africa. Struik, 1964

Van Warmelo, N. J.:

(a) Grouping and ethnic history, in: The Bantu Speaking Tribes of South Africa. Maskew Miller, 1937 (1956).

(b) Taalkaart van Suid-Afrika. Pretoria, 1952.

Young, B. A.: Bechuanaland. H.M.S.O., 1966.

Williams, D.: The changing rôle of Chiefs in Africa. Optima, Dec. 1966.

Ander:

Botswana Independence Bill. (Bill No. 62).

Lesotho Independence Bill. (Bill No. 87).

Lesotho Independence Act, 1966.

Lesotho Independence Order, 1966.

Swaziland Constitution Order, 1967. 